\title{
TEACHERS' ATTITUDE TOWARDS PEER OBSERVATION AT NAJRAN UNIVERSITY: A CASE STUDY
}

\author{
Soada Idris Khan \\ The Preparatory Year Program, Najran University, King of Saudi Arabia \\ E-mail:khan.soada@gmail.com
}

\begin{abstract}
APA Citation: Khan, S. I. (2019). Teachers' attitude towards peer observation at Najran University: A case study. English Review: Journal of English Education, 8(1), 27-32. doi: 10.25134/erjee.v8i1.2350.
\end{abstract}

Received: 08-10-2019

Accepted: 10-11-2019

Published: 01-12-2019

\begin{abstract}
The present research paper aims to analyze teachers' attitude towards peer-observation and suggest remedies to improve practice of peer-observation. As part of the methodology, the researcher selected twenty questionnaires as a sample of this study. Twenty teachers involved in peer-observation (as observer and participants) were also interviewed and their suggestions and opinions were taken into consideration to improve practice of peer-observation at PYP, Najran University. The analysis of data showed that teachers do not whole-heartedly support peer-observation. The study also found that most of the teachers are not well familiar with the concept and application of peer-observation. They often consider evaluation as an excuse to termination. The study accomplishes that a teachers' performance/ability cannot be judged in 20-30 minutes. Therefore, the study recommends that there must be many peer-observations for the same class and the best one must be assessed. The study also suggests organizing seminars and workshops to orient teachers to the process and advantages of peer-observation.
\end{abstract}

Keywords: teachers' attitude; evaluation; teaching practices; peer-observation.

\section{INTRODUCTION}

Teachers usually do not like their classes to be observed especially when the observee is more qualified and experienced than the observers. They do not wholeheartedly welcome feedback form their juniors. Moreover, remaining completely unbiased, honest and true is also a big challenge for the observers. Richardson (2000), in a study designed to improve teaching methods in his teaching establishment, found that requests to visit another teacher's classroom were met with suspicion and mistrust. Observees get more anxious and tense while someone comes to observe their classes though they are very good teachers. A psychological fear does not allow observee perform in a natural way. It is observed that some of the observees get so furious and tense that they cannot even speak properly. Fear of being terminated, even in formative evaluation, does not let them perform well. It is attributed to teachers' fear of being judged since any kind of observation is synonymous with evaluation. It seems it is not so much a matter of being watched that causes the uneasiness about peer observation, but the fear of being evaluated (Richardson, 2000). Some novice teachers are more nervous as they have never been observed. Often, it is seen, that observers themselves are not well trained for the job. They participate in the process just to obey administrative orders, not willingly.
However, various teachers expressed their utmost satisfaction with the practice of peer-observation. They admitted peer-observation helped them reflect on their own teaching and feedback was quite rewarding for them.

In this regards, Richards and Farrell (2005, p. 85) defines peer observation as "a teacher or other observer closely watching and monitoring a language lesson or part of a lesson in order to gain an understanding of some aspect of teaching." It is such a collaborative practice that offers opportunity for interchange and whose power resides in its collegial orientation and its exposure of colleagues to a variety of experiences through exchange of ideas (Marshal, 2004, cited in Donnelly, 2007, p. 29). Moreover, Hammersley-Fletcher and Ormond (2005), in a study of teachers' views on peer observation, found a number of areas for concern: anxiety over giving and receiving feedback, the possibility of collegial relationships being damaged, not knowing what was required of them and the time involved in the process were all areas perceived by teachers to present difficulties. However, one teacher did acknowledge that, in time, peer observation could be effective and another that it could lead to improved relationships with colleagues they previously had little contact.

Peer observation is presented as a developmental mode of observation that aims at 


\section{Soada Idris Khan}

Teachers' attitude towards peer observation at Najran University: A case study

improvement of performance by identifying strengths and weaknesses through reflection and provision of feedback in a collaborative environment (Cosh, 1999). As far as reflection is concerned, the peer observation process promotes a more systematic and focused approach to it. Scrivener (1994) states that teachers are expected to demonstrate the ability to identify their own strengths and weaknesses, to take steps to remedy the latter, and to carry out effective selfevaluations of their own teaching (cited in Brandt, 2008, p. 43).

The feedback received will help identify ill practices, resulting in improving teaching skills, while persuasive feedback on a teacher's ability to teach well will also result in enhancing teacher self-efficacy, thus, leaving teachers more confident to implement more groundbreaking techniques (Donnelly, 2007). Thus, there is no doubt in the fact that peer-observation is a very important practice and it must be continued. Teachers usually advocate the importance and positive aspects of peer-observation. However, there are also some doubts, fears that must be taken into account. The present study attempts to take into account teachers' attitude (positive and negative) towards peer-observation as well as to suggest remedies to improve practice of peerobservation.

\section{METHOD}

This action research analyses teachers' attitude towards peer-observation. Wallace (1998, p. 4) defines action research as "... systematically collecting data on your everyday practice and analyzing it in order to come to some decisions about what your future practice should be." The study, thoroughly, analyzes data collected from teachers, especially to find out teachers' attitude towards peer-observation and provide some suggestions, based on the findings, to improve practice of peer-observation. As Wallace (1998) states, "action research involves the collection and analysis of data related to some aspect of our professional practice; this is done so that we can reflect on what we have discovered and apply it to our professional action" (p. 16). This process is followed in this research. At the core of this process was a sincere effort to eliminate psychological fear of observee and improve the practice of peer-observation at PYP, Najran University, by bringing changes where needed.

To collect the data, the researchers circulated the questionnaire to forty participants and thirty were returned. Finally, twenty questionnaires given serious attention were selected as a sample of this research. Twenty teachers involved in peer-observation (as observer and observee) were also interviewed and their suggestions and opinions were taken into consideration to improve practice of peer-observation at PYP, Najran University.

\section{RESULTS AND DISCUSSION}

The discussion of the findings is divided into two parts; the first contains a detailed analysis and discussion on the statements of the questionnaire and the second one contains a detailed analysis and discussion on the responses of interview.

\section{Questionnaire analysis}

Reed (1989) is of the opinion that Likert-type rating scale should be used to generally gather data. Jung, Osterwalder and Wipf (2000) support the Likert scale by stating: "this was the only assessment instrument I found that was practical for the classroom" (p.2). To interpret the level of means, the authors applied Rahaya and Salbiah's (1996) model of explaining means as summarized in Table 1.

Table 1. Score category breakdown adopted from Rahayu and Salbiah (1996)

\begin{tabular}{cc}
\hline Means & Corresponding level \\
\hline $1.0-1.80$ & Very low \\
$1.81-2.60$ & Low \\
$2.61-3.40$ & Moderate \\
$3.41-4.20$ & High \\
$4.21-5.0$ & Very high \\
\hline
\end{tabular}

Table 2. Descriptive statistics of the survey's statements and discussion result

\begin{tabular}{|c|c|c|c|c|c|c|c|}
\hline $\begin{array}{c}\text { S. } \\
\text { No. } \downarrow \text {. }\end{array}$ & $\begin{array}{r}\text { Scales } \rightarrow \\
\text { Statements } \downarrow\end{array}$ & $\begin{array}{c}5 \\
\text { Strongly } \\
\text { agree }\end{array}$ & $\begin{array}{c}4 \\
\text { Agree }\end{array}$ & $\begin{array}{c}3 \\
\text { Can`t } \\
\text { say }\end{array}$ & $\begin{array}{c}2 \\
\text { Disagree }\end{array}$ & $\begin{array}{c}1 \\
\text { Strongly } \\
\text { disagree }\end{array}$ & Mean \\
\hline & $\begin{array}{l}\text { Peer-observation increases } \\
\text { nervousness/anxiousness of }\end{array}$ & $\begin{array}{c}3 \\
15 \%\end{array}$ & $\begin{array}{c}12 \\
60 \%\end{array}$ & $\begin{array}{c}4 \\
20 \%\end{array}$ & $\begin{array}{c}1 \\
5 \%\end{array}$ & $\begin{array}{c}0 \\
0 \%\end{array}$ & 3.85 \\
\hline
\end{tabular}

the observe 
2. Observee is more qualified and experienced than the observers

3. Observers usually tend to compare, a natural phenomenon which can potentially be beneficial to teachers if used in a positive way

4. Observers and observees are reluctant giving and receiving feedback

5. Observers' evaluation is influenced when they find observee using same methodologies and techniques in the classroom that they usually do

6. The feedback given by observers was helpful in improving teaching instructions

7. Observers are biased when observing the observee because of individual differences

8. Peer-observation is an essential activity to bring professional development

9. The opportunity to observe, compare and reflect allows to absorb new ideas and encourage questioning our own teaching and values and, leading to selfevaluation.

10. It is essential that the two observers who go to observe a class must have mutual respect and trust

$\begin{array}{cccccc}5 & 10 & 3 & 2 & 0 & 3.9 \\ 25 \% & 50 \% & 15 \% & 10 \% & 0 \% & \\ 2 & 13 & 2 & 3 & 0 & 3.7 \\ 10 \% & 65 \% & 10 \% & 15 \% & 0 \% & \end{array}$

$\begin{array}{cccccc}5 & 6 & 4 & 5 & 0 & 3.5 \\ 25 \% & 30 \% & 20 \% & 25 \% & 0 \% & \\ 2 & 7 & 8 & 3 & 0 & 3.4 \\ 10 \% & 35 \% & 40 \% & 15 \% & 0 \% & \end{array}$

$\begin{array}{cccccc}0 & 12 & 8 & 0 & 0 & 3.6 \\ 0 \% & 60 \% & 40 \% & 0 \% & 0 \% & \end{array}$

$\begin{array}{cccccc}4 & 10 & 1 & 5 & 0 & 3.65 \\ 20 \% & 50 \% & 5 \% & 25 \% & 0 \% & \end{array}$

$\begin{array}{cccccc}6 & 6 & 2 & 5 & 1 & 3.55 \\ 30 \% & 30 \% & 10 \% & 25 \% & 5 \% & \\ 0 & 8 & 8 & 4 & 0 & 3.2 \\ 0 \% & 40 \% & 40 \% & 20 \% & 0 \% & \end{array}$

$\begin{array}{cccccc}2 & 12 & 2 & 4 & 0 & 3.6 \\ 10 \% & 60 \% & 10 \% & 20 \% & 0 \% & \\ & & & & & \\ \end{array}$

The first statement in the questionnaire Peerobservation increases nervousness/anxiousness of the observe reveals that there are $15 \%$ participants who felt Peer-observation increases nervousness/anxiousness of the observee. $60 \%$ of the participants admitted to it, though (20\%) of the participants did not express their opinion. $5 \%$ of the participants disagreed. The mean of the statement is 3.85 that lies in the category of 'High' as per the breakdown adopted from the scale of Rahaya and Salbiah (1996).

The second statement in the questionnaire Observee is more qualified and experienced than the observers displays that there are $25 \%$ of the participants who opined that the observee is more qualified and experienced than the observers. $50 \%$ of the participants agreed, though (15\%) of the participants had no idea. $10 \%$ of the participants did not accept the statement. The mean is categorized as high.

The third statement in the questionnaire Observers usually tend to compare, a natural phenomenon, which can potentially be beneficial to teachers if used in a positive way, shows that $10 \%$ of the participants are of the opinion that observers usually tend to compare, a natural phenomenon, which can potentially be beneficial to teachers if used in a positive way. $65 \%$ of the participants agreed to the statement, though $10 \%$ of the participants had no opinion. $15 \%$ of the participants dissented. The mean is high.

The fourth statement in the questionnaire Observers and observees are reluctant giving and receiving feedback exhibits that there are $25 \%$ of 


\section{Soada Idris Khan}

Teachers' attitude towards peer observation at Najran University: A case study

the participants who strongly agreed that observers and observees are reluctant giving and receiving feedback. $30 \%$ of the participants also admitted to it. $25 \%$ of the participants disagreed to the statement. $20 \%$ had no response, while there was none who strongly disagreed. The mean is ranked as High.

The fifth statement in the questionnaire Observers' evaluation is influenced when they find observee using same methodologies and techniques in the classroom that they usually do divulges that there are $10 \%$ of the participants who strongly agreed to the statement that observers' evaluation is influenced when they find observee using same methodologies and techniques in the classroom that they usually do. $35 \%$ of the participants agreed with the statement, though (40\%) of the participants did not express their opinion. $15 \%$ of the participants disapproved. The mean is moderate.

The sixth statement in the questionnaire The feedback given by observers was helpful in improving teaching instructions discloses that there is none who strongly agreed to the statement. $60 \%$ of the participants concurred that the feedback given by observers was helpful in improving teaching instructions. $40 \%$ of the participants were not sure about it. There is none with disagreement. The mean is high.

The seventh statement in the questionnaire Observers are biased when observing the observee because of individual differences shows that $20 \%$ of the participants stated that observers are biased when observing the observee because of individual differences. $50 \%$ of the participants accepted the statement and 5\% of the participants had no opinion. $25 \%$ of the participants did not accept the statement. The mean is categorized as high.

The eighth statement in the questionnaire Peer-observation is an essential activity to bring professional development unveils that $30 \%$ of the participants were in absolute agreement to the statement that peer-observation is an essential activity to bring professional development. An equal number $(30 \%)$ of the participants agreed, while $10 \%$ of the participants did not state an opinion. $25 \%$ of the participants did not agree with the statement and 5\% were in absolute disagreement. The mean falls in the category of high.

The ninth statement in the questionnaire The opportunity to observe, compare and reflect allows to absorb new ideas and encourage questioning our own teaching and values and, leading to self-evaluation reveals no participant thought that the opportunity to observe, compare and reflect allows to absorb new ideas and encourage questioning our own teaching and values and, leading to self-evaluation. $40 \%$ of the participants agreed with the statement, though the same number (40\%, a significant percentage) of the participants had no opinion. $20 \%$ of the participants disagreed with the statement. The mean is placed as moderate.

The tenth statement in the questionnaire It is essential that the two observers who go to observe a class must have mutual respect and trust reveals that $10 \%$ of the participants strongly agreed with the statement that it is essential that the two observers who go to observe a class must have mutual respect and trust. $60 \%$ of the participants agreed to it, while $10 \%$ of the participants did not express their opinion. 20\% of the participants did not agree with the statement. The mean is ranked as high.

\section{Interview analysis}

Another method used to collect the data was interviewing teachers. Twenty samples filled in with complete information were selected for the study. The participants responded to the following questions:

1. How was peer-observation helpful in improving teaching instruction?

2. What are the barriers in the practice of peer-observation?

3. Please provide suggestions for improving practice of peer-observation!

Table 3. Results of interview question no. 1

\begin{tabular}{cl}
\hline Q.1. Number of participants & How was peer-observation helpful in improving teaching instruction: \\
\hline 5 & $\begin{array}{l}\text { It helped reflect on our own teaching } \\
\text { It helped us develop professionally } \\
\text { Peer-observation promotes collaborative work }\end{array}$ \\
& $\begin{array}{l}\text { It helped develop confidence } \\
\text { Evaluation affirmed that teaching methodologies and techniques were } \\
\text { successful for a particular class } \\
\text { It exposed to different teaching styles }\end{array}$
\end{tabular}


Feedback was helpful in improving teaching

It makes feel good when colleagues appreciate good points of teaching instructions

As shown in Table 3, in response to their confidence level and affirmed their question number 1, there were varied teaching methodologies, techniques and style responses. Only common and recurrent were appropriate for the particular classroom. responses are listed above. Many teachers Meanwhile, feedback helped improve agreed that peer-observation helped boost teaching further and develop professionally.

Table 4. Results of interview question no. 2

\begin{tabular}{cl}
\hline Q.2 Number of participants & \multicolumn{1}{c}{ What are the barriers in the practice of peer-observation } \\
\hline 5 & $\begin{array}{l}\text { Observers are not qualified enough to comment on colleagues' } \\
\text { teaching } \\
\text { It is too much time consuming in planning and executing }\end{array}$ \\
& $\begin{array}{l}\text { It often leads to biased commentary because of individual differences } \\
\text { The department doesn't always provide stress free environment for } \\
\text { peer-observation } \\
\end{array}$ \\
& $\begin{array}{l}\text { Peer-observation is not always reliable because observee often loses } \\
\text { his natural style of teaching out of fear and nervousness } \\
\text { Observers and observees reach to an understanding of favoring each } \\
\text { other in their respective session as their roles are often mutually } \\
\text { switched }\end{array}$ \\
\hline
\end{tabular}

As shown in Table 4, in response to becomes victim of individual differences. The question number 2, there were some common department does not always provide stressbarriers in the practice of peer-observation. A free environment. Peer-observation cannot be majority of teachers believe (as shown in reliable as observee often gets nervous and responses) that peer-observation often loses his natural style of teaching.

Table 5. Results of interview question no. 3

\begin{tabular}{lll}
\hline Q.3 & Number of participants & \multicolumn{1}{c}{ Suggestions for improving practice of peer-observation: } \\
\hline 8 & $\begin{array}{l}\text { Observers must be especially trained for peer-observation } \\
\text { There must be workshops and seminars on peer-observation to orient } \\
\text { faculty to its concept and advantages }\end{array}$ \\
& $\begin{array}{l}\text { External faculty should be called to evaluate to eliminate the fear of } \\
\text { biasness } \\
\text { There must be a follow-up session on the feedback of peer-observers }\end{array}$ \\
& $\begin{array}{l}\text { Observee must be rewarded for good performance } \\
\text { Classroom teaching must be recorded and then evaluated by a } \\
\text { committee of expert }\end{array}$ \\
\hline
\end{tabular}

As shown in Table 5, in response to question number 3 , there were some common suggestions by the teachers. The common suggestions were that observers must be specially trained for peer-observation. Respondent should also be oriented to the benefits of peer-observation by conducting workshop and seminars. External faculty should be called for peer-observation to make the evaluation more reliable.

\section{CONCLUSION}

The results of the questionnaire exhibit that most of the statements fall in the category of high as per the breakdown adopted for the study. It proves that most of the teachers are in favor of peer-observation. 8 out of 10 statements score high, while the rest two fall in the category of moderate. However, none of the statements scores very high. It shows that teachers do not whole-heartedly support peer-observation. The study also finds that most of the teachers are not well familiar with 


\section{Soada Idris Khan}

Teachers' attitude towards peer observation at Najran University: A case study

the concept and application of peerobservation. They often consider evaluation as an excuse to termination. That is one of the reasons that teachers (observee) get nervous as soon as observers enter the classroom. They lose their natural style of teaching.

Peer-observation does more harm than good for these anxious/nervous teachers. A teachers' performance/ability cannot be judged in 20-30 minutes. Therefore, the study recommends that there must be many peerobservations for the same class and the best one must be assessed. Observeee must be given sufficient time to feel comfortable with the practice of peer-observation. Students should also be allowed to participate in the evaluation as they are the real evaluators and often unbiased. The best way is to provide teacher/observee a camera and record his/her lecture to be subsequently evaluated by a committee of expert on peer-observation. It is also not a good practice that observers, without prior training, are commanded to evaluate teaching performance of an observee that is highly technical in its nature and requires a considerable amount of training.

Besides, there should be some arrangement to reward (a financial one) a good performer, as it will motivate him to do better. Moreover, it will encourage colleagues to compete with each other and thus improve their performance in a healthy competitive environment. Feedback should be given in a healthy and non-judgmental way. The data gathered through the observation tool are analyzed and, during the ensuing discussion, explicit feedback is provided in a nonjudgmental manner (Edge, 1992; Gosling, 2002; Hendry \& Oliver, 2012).

Further, there should be seminars and workshops to orient teachers to the process and advantages of peer-observation. Kotsiomyti (2010, p. 264-265) has asserted that "the overwhelming majority of teachers have never participated in a peer observation process, while those having participated in one have done so only once, thus leading to the formation of attitudes based on little or no experience on the subject, accounting for the creation of the association aforementioned.
Moreover, peer observation is considered to have been executed poorly, with the pre- and post- stages of the observation being inadequately realized or entirely absent from the process."

\section{REFERENCES}

Brandt, (2008). Integrating feedback and reflection in teacher preparation. ELT Journal, 62(1), 37-46.

Cosh, J. (1999). Peer observation: A reflective model. ELT Journal, 53(1), 22-27.

Donnelly, R. (2007). Perceived impact of peer observation of teaching in higher education. International Journal of Teaching and Learning in Higher Education, 19(2), 117-129.

Gosling, D. (2002). Models of peer observation of teaching, learning, and teaching support. Network, 2-5.

Hammersley-Fletcher, L., \& Orsmond, P. (2005). Reflecting on reflective practices within peer observation. Studies in Higher Education, 30(2), 213- 224.

Hendry, G. D., \& Oliver, G. R. (2012). Seeing is believing: The benefits of peer observation. Journal of University Teaching and Learning Practice, 9(1), 1-9.

Jung, T., Osterwalder, H., \& Wipf, D. (2000). Teaching and assessing middle-year students' speaking and listening skills. Teaching and Learning Research Exchange. Retrieved from: http://www.mcdowellfoundation.ca/main_mcdo well/projects/research_rep/52_teaching_assessin g.pdf.

Kotsiomyti, M. (2010). Teacher observation and Greek state teachers of English: Current practices and suggestions for improvement. Language Learning/Teaching - Education, 1, 197-214.

Rahaya, S. A., \& Salbiah, M. (1996). Pemikiran guru cemerlang: Kesan teradap prestasi pengajaran: Kertas kerja seminar isu-isu pendidikan. Fakulti pendidikan, Universiti Kebangsaan Malaysia.

Reed, V. (1989). Adolescent language disorders: General strategies for teaching language comprehension/listening. Eau Claire, WI: Thinking Publications.

Richards, J. C., \& Farrell, T .S. C. (2005). Professional development for language teachers: Strategies for teacher learning. Cambridge: Cambridge University Press.

Richardson, M. (2000). Peer observation: Learning from one another. The NEA Higher Education Journal, Summer.

Wallace, M. J. (1998). Action research for language teachers. Cambridge: Cambridge University Press. 